\title{
PROCEDIMIENTO PARA PREDECIR LA NECESIDAD DE ABONOS EN CULTIVOS HORTÍCOLAS
}

\author{
Bouzo, C. A. ${ }^{1}$; Astegiano, E. D. ${ }^{1}$ \& Favaro, J. C. ${ }^{1}$
}

\section{RESUMEN}

Para determinar dosis de fertilizantes en abonado de cultivos hortícolas es usual la realización de experimentos con diseños estadísticos apropiados, en distintas regiones y sistemas de manejo. Otra opción es la predicción basada en atributos inherentes al cultivo y al medio agrofísico. El objetivo de este trabajo fue adaptar un procedimiento matemático, denominado racional, para estimar requerimientos de nitrógeno $(\mathrm{N})$, fósforo $(\mathrm{P})$ y potasio $(\mathrm{K})$ de cultivos hortícolas. Se calcularon dosis en cada cultivo considerando: a) demanda N, P y K con relación a algunos atributos específicos; b) suministro de nutrientes proporcionado por el suelo y c) eficiencia con que los nutrientes son absorbidos por las raíces. Se evaluó el procedimiento a través de la demanda de N, P y K de algunos cultivos hortícolas mediante comparación con sus extracciones determinadas experimentalmente. El coeficiente de determinación fue mayor a 0,8 indicativo de una buena aproximación a los requerimientos reales.

Palabras clave: procedimiento matemático, demanda, nitrógeno, fósforo, potasio.

\section{SUMMARY}

\section{Procedure to predict the necessity of fertilizer in vegetables crops.}

To determine fertilizers dose in vegetables crops is common the realization of experiments with appropriate statistical designs, in different regions and production systems. Another option is the prediction based on inherent attributes of the crops and the agrophysic environment. The aim of this work was to adapt a mathematical procedure to estimate requirements of nitrogen $(\mathrm{N})$, phosphorus (P) and potassium $(\mathrm{K})$ in vegetables crops. In each crop the doses was calculated considering: a) demands of N, P and K with relationship to some specific attributes; b) nutrients provided by the soil and c) efficiency with which the nutrients are absorbed by the roots. The procedure was evaluated through the demand of N, P and K of some vegetables crops by comparison with the extractions experimentally. The determination coefficient was upper to 0,8 indicating a good approach to the experimentally requirements.

Key words: mathematical procedure, demand, nitrogen, phosphorus, potassium.

1.- Cátedras de Horticultura y Fisiología Vegetal. Facultad de Ciencias Agrarias, Universidad Nacional del Litoral. Kreder 2805. (3080) Esperanza, provincia de Santa Fe. Telefax: (03496) 426400. E-mail: cbouzo@ fca.unl.edu.ar

Manuscrito recibido el 29 de febrero de 2003 y aceptado para su publicación el 15 de abril de 2003. 